\title{
Mesenchymal Stem Cells in the Dental Tissues: Perspectives for Tissue Regeneration
}

\author{
Carlos ESTRELA ${ }^{1}$ \\ Ana Helena Gonçalves de ALENCAR ${ }^{1}$ \\ Gregory Thomas KITTEN ${ }^{2}$ \\ Eneida Franco VENCIO ${ }^{1}$ \\ Elisandra GAVA ${ }^{1,2}$ \\ ${ }^{1}$ Dental School, UFG - Federal University of Goiás, Goiânia, GO, Brazil
${ }^{2}$ Institute of Biological Sciences, UFMG - Federal University of Minas Gerais, Belo Horizonte, MG, Brazil
}

\begin{abstract}
In recent years, stem cell research has grown exponentially owing to the recognition that stem cell-based therapies have the potential to improve the life of patients with conditions that range from Alzheimer's disease to cardiac ischemia and regenerative medicine, like bone or tooth loss. Based on their ability to rescue and/or repair injured tissue and partially restore organ function, multiple types of stem/progenitor cells have been speculated. Growing evidence demonstrates that stem cells are primarily found in niches and that certain tissues contain more stem cells than others. Among these tissues, the dental tissues are considered a rich source of mesenchymal stem cells that are suitable for tissue engineering applications. It is known that these stem cells have the potential to differentiate into several cell types, including odontoblasts, neural progenitors, osteoblasts, chondrocytes, and adipocytes. In dentistry, stem cell biology and tissue engineering are of great interest since may provide an innovative for generation of clinical material and/or tissue regeneration. Mesenchymal stem cells were demonstrated in dental tissues, including dental pulp, periodontal ligament, dental papilla, and dental follicle. These stem cells can be isolated and grown under defined tissue culture conditions, and are potential cells for use in tissue engineering, including, dental tissue, nerves and bone regeneration. More recently, another source of stem cell has been successfully generated from human somatic cells into a pluripotent stage, the induced pluripotent stem cells (iPS cells), allowing creation of patientand disease-specific stem cells. Collectively, the multipotency, high proliferation rates, and accessibility make the dental stem cell an attractive source of mesenchymal stem cells for tissue regeneration. This review describes new findings in the field of dental stem cell research and on their potential use in the tissue regeneration.
\end{abstract}

Key Words: Endodontics, stem cell, dental stem cell, tissue engineering.

\section{INTRODUCTION}

The discovery of stem cells and recent advances in cellular and molecular biology has led to the development of novel therapeutic strategies that aim at the regeneration of many tissues that were injured by disease. Generally, stem cells have two major properties: they are capable of self-renewal and, upon division, they can give rise to cells that have the potential to differentiate (1). Tissue engineering is a multidisciplinary field that combines biology, engineering, and clinical science with the goal of generating new tissues and organs. It is a science based on fundamental principles that involves the identification of appropriate cells, the development of scaffolds and morphogenic signals required to induce cells to regenerate a tissue or organ (2). Over the last few years, medicine has begun to explore the possible applications of stem cells and tissue engineering towards the repair and regeneration body structures (3). It is becoming ever more clear that this conceptual come up to therapy, named regenerative medicine, will have its place in clinical practice in the future. It has been shown that stem cells will play an important role in future medical treatments because they can be readily grown and induced to differentiate into any cell type in culture.

Stem cells are cells that have the ability to renew themselves through mitosis and can differentiate into several specialized cells. The embryonic stem cells (ESC) are pluripotent and have the ability to become almost any kind of cell of the body (4). The local microenvironment

Correspondence: Profa. Dra. Elisandra Gava, Departamento de Ciências Estomatológicas, Universidade Federal de Goiás, Praça Universitária S/N, Setor Universitário, 74605-220 Goiânia, GO, Brasil. Tel: +55-62-3209-6053. e-mail: elisandragava@yahoo.com.br 
represents an important compartment in maintaining the stem cells status. The microenvironment regulates the balance between self-renewal and differentiation. This intercellular communication has been characterized between embryonal carcinoma cells and stromal cells, and indicates changes in the expression on both cellular compartments (5).

Scientists can induce these cells to replicate themselves in an undifferentiated state. However, the use of ESC is controversial and associated with ethical and legal issues, thus conditioning their application for the development of new therapies (4).

Another source of stem cells is the umbilical cord. Blood from the umbilical cord contains stem cells that are genetically identical to those of the newborn baby. These cells are multipotent, and are able to differentiate into certain cell types. Umbilical cord stem cells can be stored cryogenically after birth for use in a future medical therapy (2).

Mesenchymal stem cells (MSC) are multipotent progenitor cells, originally isolated from adult bone marrow and subsequently from other tissues in both adult and fetal life. Adult stem cells normally generate cell types of the tissue in which they reside. However, studies have shown that stem cells from one tissue could generate cell types of a completely different tissue (3).

Unlike ESC, adult stem cells have the potential to be used for treatment of regenerative disease, cardiac ischemia, and bone or tooth loss. Future applications for stem cells include the treatment of Parkinson's disease and cancer (5). The use of adult stem cells in research and medical applications is less controversial because they can be harvested without destroying an embryo. Postnatal stem cells have been found in almost all body tissues, including dental tissues. Dental stem cells have been identified as candidates for tissue engineering (6). Because of their multipotent differentiation ability, they provide an alternative for use in regenerative medicine since they can be used for not only to dental tissue regeneration, but also to facilitate repair of non-dental tissues such as bone and nerves $(6,7)$.

A new source of stem cell has been generated from human somatic cells into a pluripotent stage, the induced pluripotent stem cells (iPS cells) $(8,9)$. iPS cells resemble human ESC and can differentiate into advanced derivates of all three primary germ layers. Unlike ESC, iPS cell technology can derive patient-specific stem cells allowing derivation of tissue-matched differentiation donor cells for basic research, disease modeling, and regenerative medicine (9). This technology might be the new era of personalized medicine.

This review discusses the perspectives in the field of stem cell-based regenerative medicine, addressing sources of stem cells identified in dental tissues; and new findings in the field of dental stem cell research and their potential use in the dental tissue engineering.

Several cell populations with stem cells properties have been isolated from different parts of the tooth. Since the discovery of the existence of adult stem cells from the dental pulp in 2000 (10), several other types of dental stem cells have been successively isolated from mature and immature teeth, including stem cells derived from exfoliated deciduous teeth (11), stem cells derived from the apical papilla (12), MSC from tooth germs (13) and from human periodontal ligament (PDL) (14). It is considered that these stem cells are undifferentiated mesenchymal cells present in dental tissues and characterized by their unlimited self-renewal, colony forming capacity, and multipotent differentiation (1). During the characterization of these newly identified dental stem cells, certain aspects of their proprieties have been compared with those of bone-marrow-derived stromal stem cells (BMMSC). Dental stem cells display multidifferentiation potencial, with the capacity to give rise to distinct cell lineages, osteo/osteogenic, adipogenic, and neurogenic. Therefore, these cells have been used for tissue-engineering studies to assess their potential in preclinical applications (6).

It is, however, important to consider that, although different types of dental-tissue derived MSC share several common characteristics and present significant heterogeneity, expressed by multiple phenotypic differences, which most probably reflect distinct functional properties (1). There is already evidence that there are significant variations, for example, in the odontogenic potential of single colony-derived populations isolated from the dental pulp, reflecting differences in their genotypic and protein expression patterns (15). In addition, this heterogeneity may be significantly enhanced as a function of their tissue microenvironment (16). This issue becomes more complicated as researchers have used quite different methods to isolate and culture dental MSC and evaluate their differentiation potential.

\section{DENTAL PULP STEM CELLS}

The first stem cells isolated from adult human 
dental pulp were termed dental pulp stem cells (DPSC). They were isolated from permanent third molars and exhibited high proliferation and high frequency of colony formation that produced calcified nodules (10). DPSC cultures from impacted third molars at the stage of root development were able to differentiate into odontoblastlike cells with a very active migratory and mineralization potential, leading to organized three-dimensional dentinlike structures in vitro (17).

There are different cell densities of the colonies in DPSC, suggesting that each cell clone may have different grown rate (10). Different cell morphologies and sizes can be observed in the same colony. The differentiation of DPSC to a specific cell lineage is mainly determined by the components of local microenvironment, such as, growth factors, receptor molecules, signaling molecules, transcription factors and extracellular matrix protein. DPSC can be reprogrammed into multiple cell lineages such as, odontoblast, osteoblast, chondrocyte, myocyte, neurocyte, adipocyte, corneal epithelial cell, melanoma cell, and even induced pluripotent stem cells (iPS cells) $(18,19)$. Almushayt et al. (20) demonstrated that dentin matrix protein 1 (DMP1), a non-collagen extracellular matrix protein extract from dentin, can significantly promote the odontoblastic differentiation of DPSC and formation of reparative dentin over the exposed pulp tissue. Additionally, DPSC can be induced into odontoblast lineage when treated with transforming growth factor $\beta 1$ (TGF $\beta 1$ ) alone or in combination with fibroblast growth factor $\left(\mathrm{FGF}_{2}\right)(21)$.

Histologically, dentin lies outside of dental pulp, and they intimately link to each other. Functionally, dental pulp cells can regenerate dentin and provide it with oxygen, nutrition and innervation, whereas the hard dentin can protect soft dental pulp tissue. Together, they maintain the integrity of tooth shape and function. Any physiological or pathological reaction occurring at one part, such as trauma, caries, and cavity preparation, will affect the other. Both of them act as a dentin-pulp complex and simultaneously participate in various biological activities of the tooth. Several studies have shown that DPSC play a vital role in the dentin-pulp tissue regeneration (10). In vivo transplantation into immunocompromised mice DPSC demonstrated the ability to generate functional dental tissue in the form of dentin/pulp-like complexes (22). Transplanted ex vivo expanted DPSC mixed with hydroxyapatite/ tricalcium phosphate form ectopic dentin/pulp-like complexes in immunocompromised mice. These polls of heterogeneous DPSC form vascularizad pulp like tissue and are surrounded by a layer of odontoblast-like cells expressing factors that produce dentin containing tubules similar those found in natural dentin $(22,23)$. Huang et al. (24) reported that dentin-pulp-like complex with well-established vascularity can be regenerated de novo in emptied root canal space by DPSC. These studies provide a novel advance for future pulp tissue preservation and a new alternative for the biological treatment for endodontic diseases.

In addition, DPSC can express neural markers and differentiate into functionally active neurons, suggesting their potential as cellular therapy for neuronal disorders (7). In recent study, DPSC were transplanted into the cerebrospinal fluid of rats in which cortical lesion was induced. Those cells migrated as single cells into a variety of brain regions and were detected in the injured cortex expressing neuron specific markers. This showed that DPSC-derived cells integrate into the host brain may serve as useful sources of neuro and gliogenesis in vivo, especially when the brain is injured (25). The spontaneous differentiating potential of these cells strongly suggests their possible applications in regenerative medicine.

\section{STEM CELLS FROM HUMAN EXFOLIATED DECIDUOUS TEETH}

Stem cells may be also isolated from the pulp of human exfoliated deciduous teeth (SHED). These cells have the capacity of inducing bone formation, generate dentin and differentiate into other nondental mesenchymal cell derivatives in vitro. SHED exhibit higher proliferation rates, increased population doublings, in addition to osteoinductive capacity in vivo and an ability to form sphere-like clusters. However, unlike DPCSs, they are unable to regenerate complete dentin/pulp-like complexes in vivo (10). With the osteoinductive potential, SHED can repair critical sized calvarial defects in mice with substantial bone formation (26). Given their ability to produce and secrete neurotrophic factors, dental stem cells may also be beneficial for the treatment of neurodegenerative diseases and the repair of motor neurons following injury. Indeed, dental stem cells from deciduous teeth have been induced to express neural markers such as nestin (27). The expression of neural markers in dental stem cells stimulates the imagination for their potential use in neural regeneration such as in the treatment of 
Parkinson's disease. The potential of dental stem cells in non-dental regeneration continues to be further explored by researchers.

\section{STEM CELLS FROM APICAL PAPILLA}

The physical and histological characteristics of the dental papilla located at the apex of developing human permanent teeth has been recently been described and this tissue has been termed apical papilla. This tissue is loosely attached to the apex of the developing root and can be easily detached. A population of stem cells isolated from human teeth was found at the tooth root apex. These cells are called stem cells from apical papilla (SCAP) and have been demonstrated to differentiate exhibit higher rates of proliferation in vitro than do DPSC. There is an apical cell-rich zone lying between the apical papilla and the pulp. Importantly, stem/progenitor cells were located in both dental pulp and the apical papilla, but they have somewhat different characteristics (12). The higher proliferative potential of SCAP makes this population of cells suitable for cell-based regeneration and preferentially for forming roots. They are capable of forming odontoblast-like cells and produce dentin in vivo and are likely to be the cell source of primary odontoblasts for the root dentin formation (12). The discovery of SCAP may also explain a clinical phenomenon that was presented in a number of recent clinical case reports showing that apexogenesis can occur in infected immature permanent teeth with apical periodontitis or abscess (28). It is likely that SCAP residing in the apical papilla survived the infection due to their proximity to the periapical tissues. This tissue may be benefited by its collateral circulation, which enables it to survive during the process of pulp necrosis. Perhaps, after endodontic disinfection, these cells give rise to primary odontoblasts to complete the root formation.

\section{PERIODONTAL LIGAMENT STEM CELLS}

Periodontal ligament (PDL) is a space interlying the cementum and alveolar bone, a replacement of the follicle region surrounding the developing tooth in cap and bud stages of development. Fibers inserted into the cementum layer may be of follicle origin (termed Sharpey's fibers) or cementoblast origin (in cellular intrinsic fiber cementum). The PDL matures during tooth eruption, preparing to support the functional tooth for the occlusal forces. In the mature PDL, major collagen bundles (principal fibers) occupy the entire PDL, embedding in both cementum and alveolar bone. Fibers are arranged in specific orientations to maximize absorption of the forces to be placed on the tooth during mastication. The PDL has long been recognized to contain a population of progenitor cells and recently, studies identified a population of stem cells from human PDL capable of differentiating along mesenchymal cell lineages to produce cementoblast-like cells, adipocytes and connective tissue rich in collagen I (14). PDL stem cells (PDLSC) display cell surface marker characteristics and differentiation potential similar to bone marrow stromal stem cells and DPSC (14). After PDLSC were transplanted into immunocompromised mice, cementum/PDL-like structures were formed. Human PDLSC expanded ex vivo and seeded in threedimensional scaffolds (fibrin sponge, bovine-derived substitutes) were shown to generate bone (29). These cells have also been shown to retain stem cell properties and tissue regeneration capacity. These findings suggest that this population of cells might be used to create a biological root that could be used in a similar way as a metal implant, by capping with an artificial dental crown.

\section{DENTAL FOLLICLE PRECURSOR CELLS}

The dental follicle is a loose connective tissue that surrounds the developing tooth. The dental follicle has long been considered a multipotent tissue, based on its ability to generate cementum, bone and PDL from the ectomesenchyme-derived fibrous tissue. Dental follicle precursor cells (DFPC) can be isolated and grown under defined tissue culture conditions, and recent characterization of these stem cells has increased their potential for use in tissue engineering applications, including periodontal and bone regeneration $(12,30)$. DFPC form the PDL by differentiating into PDL fibroblasts that secrete collagen and interact with fibers on the surfaces of adjacent bone and cementum. Dental follicle progenitor cells isolated from human third molars are characterized by their rapid attachment in culture, and ability to form compact calcified nodules in vitro (30). DFPC, in common with SCAP, represent cells from a developing tissue and might thus exhibit a greater plasticity than other dental stem cells. However, in the same way as for SCAP, further research needs to be carried out on the properties and potential uses of these cells (Table 1). 


\section{DENTAL PULP STEM CELLS AND DENTAL TISSUE ENGINEERING}

There are several areas of research for which dental stem cells are presently considered to offer potential for tissue regeneration. These include the obvious uses of cells to repair damaged tooth tissues such as dentin, PDL and dental pulp $(6,24)$. Even the use of dental stem cells as sources of cells to facilitate repair of additional tissues as bone and nerves $(6,7,26)$. Efforts to induce tissue regeneration in the pulp space have been a long search. In 1962, Ostby (31) proposed inducing hemorrhage and blood clot formation in the canal space of mature teeth in the hope of guiding the tissue repair in the canal. However, the connective tissue that grew into the canal space was limited and the origin of this tissue remains unproved. Regenerative Endodontics represents a new treatment modality that focuses on reestablishment of pulp vitality and continued root development. This clinical procedure relies on the intracanal delivery of a blood clot (scaffold), growth factors (possibly from platelets and dentin), and stem cells (32). In a recent study, it was demonstrated that mesenchymal stem cells are delivered into root canal spaces during regenerative endodontic procedures in immature teeth with open apices (32). These findings provide the biological basis for the participation of stem cells in the continued root development and regenerative response that follow this clinically performed procedure.

As DPSC have the potent dentinogenic ability, they could be used for the vital pulp therapy. When DPSC are transplanted alone or in combination with BMP2 in the pulp cavity, these stem cells can significantly promote the repair and reconstruction of dentin-pulplike complex (31). Prescott et al. (34) placed the triad of DPSC, a collagen scaffold, and DMP1 in the simulated perforation sites in dentin slices, and then transplanted the recombination subcutaneously into the nude mice. After 6 weeks of incubation, well-organized pulplike tissue could be detected in the perforation site.

Table 1. Stem cell types in dental pulps $(6,7,10-15,17,18,20)$.

\begin{tabular}{|c|c|c|c|c|c|}
\hline Properties & DPSC & SCAP & SHED & PDLSC & DFPC \\
\hline Location & $\begin{array}{l}\text { Permanent } \\
\text { tooth pulp }\end{array}$ & $\begin{array}{l}\text { Apical papilla of } \\
\text { developing root }\end{array}$ & $\begin{array}{c}\text { Exfoliated } \\
\text { deciduous tooth } \\
\text { pulp }\end{array}$ & $\begin{array}{l}\text { Periodontal } \\
\text { ligament }\end{array}$ & $\begin{array}{l}\text { Dental follicle of } \\
\text { developing tooth }\end{array}$ \\
\hline Proliferation rate & Moderate & High & High & High & High \\
\hline Heterogeneity & Yes & Yes & Yes & Yes & Yes \\
\hline Multipotentialy & $\begin{array}{c}\text { Odontoblast, } \\
\text { osteoblast, } \\
\text { chondrocyte, } \\
\text { myocyte, neurocyte, } \\
\text { adipocyte, corneal } \\
\text { epithelial cell, } \\
\text { melanoma cell, iPS }\end{array}$ & $\begin{array}{l}\text { Odontoblast, } \\
\text { osteoblast, } \\
\text { neurocyte, } \\
\text { adipocyte, iPS }\end{array}$ & $\begin{array}{c}\text { Odontoblast, } \\
\text { osteoblast, } \\
\text { chondrocyte, } \\
\text { myocyte, } \\
\text { neurocyte, } \\
\text { adipocyte, iPS }\end{array}$ & $\begin{array}{l}\text { Odontoblast, } \\
\text { osteoblast, } \\
\text { chondrocyte, } \\
\text { cementoblast, } \\
\text { neurocyte }\end{array}$ & $\begin{array}{l}\text { Odontoblast, } \\
\text { osteoblast, } \\
\text { neurocyte }\end{array}$ \\
\hline Tissue repair & $\begin{array}{l}\text { Bone regeneration, } \\
\text { neuroregeneration, } \\
\text { myogenic } \\
\text { regeneration, dentin- } \\
\text { pulp regeneration }\end{array}$ & $\begin{array}{l}\text { Bone regeneration, } \\
\text { neuroregeneration, } \\
\text { dentin-pulp } \\
\text { regeneration, } \\
\text { root formation }\end{array}$ & $\begin{array}{c}\text { Bone regeneration, } \\
\text { neuroregeneration, } \\
\text { tubular dentin }\end{array}$ & $\begin{array}{l}\text { Bone regeneration, } \\
\text { root formation, } \\
\text { periodontal } \\
\text { regeneration }\end{array}$ & $\begin{array}{l}\text { Bone } \\
\text { regeneration, } \\
\text { periodontal } \\
\text { regeneration }\end{array}$ \\
\hline
\end{tabular}

DPSC = dental pulp stem cells; SCAPs = stem cells from the apical papila; SHED = stem cells from the pulp of human exfoliated deciduous teeth; PDLSC $=$ periodontal ligament stem cells; DFPC $=$ dental follicle precursor cells . 
Cordeiro et al. (35) demonstrated that SHED/scaffold recombination prepared within human tooth slices also have the potential to form dental pulp-like structures. Huang et al. (24) reported that dentin-pulp-like complex with well-established vascularity can be regenerated de novo in emptied root canal space by either DPSC or SHED (24). One of the most challenging aspects of developing a regenerative endodontic therapy is to understand how the various procedures involved can be optimized and integrated to produce the outcome of a regenerated pulp-dentin complex. The future development of regenerative endodontic procedures will require a comprehensive research program directed at each of these components and their application in the clinical practice.

Periodontitis is the most common cause for tooth loss in adults due to irreversible waste of connective tissue attachment and the supporting alveolar bone. The challenge for cell-based replacement of a functional periodontium is therefore to form new ligament and bone, and to ensure that the appropriate connections are made between these tissues, as well as between the bone and tooth root. This is not a trivial undertaking, as these are very different tissues that are formed in an ordered manner (spatially and temporally) during tooth development (36). In recent years, guided tissue regeneration has become the gold-standard surgery for periodontal tissue regeneration. This procedure involves draping a biocompatible membrane over the periodontal defect from the root surface to the adjacent alveolar bone, often in combination with a bone graft (37). The barrier membrane prevents unwanted epithelium and gingival connective tissue from entering the healing site, while promoting repopulation of the defect site by cells migrating in from the PDL (29). The rather limited success of this approach has led scientists to develop methods to improve this therapy, through the addition of exogenous growth factors and via stem cell therapy (38). One goal of current research is to use different populations of dental stem cells to replicate the key events in periodontal development both temporally and spatially, so that healing can occur in a sequential manner to regenerate the periodontium (39).

Commonly used growth factors for PDL regeneration therapies include bone morphogenetic proteins, platelet derived growth factor, Emdogain and recombinant amelogenin protein. The resultant improved regenerative capability could be related to increased recruitment of progenitor MSC, which subsequently differentiate to form PDL tissue. Recently, PDLSC transfected with expression vectors for platelet-derived growth factor and bone morphogenetic protein were investigated in periodontal tissue engineering models (40). These studies revealed the regeneration of normal periodontal tissues, containing organized cementum, alveolar bone and the PDL attachment apparatus. The possibility of constructing a root-periodontal tissue complex was further successfully demonstrated using a pelleted hydroxyapatite/tricalcium phosphate scaffold containing SCAP, coated with PDLSC-seeded Gelfoam, implanted and grown in minipig tooth socket $(11,41)$. The multipotent differentiation properties of PDLSC for generating both hard and soft tissues were further demonstrated by constructing multilayered cell sheets supported by woven polyglycolic acid. Transplanted cell seeded polyglycolic acid sheets regenerated new bone, cementum and well-oriented collagen fibers when introduced into root surfaces. In addition to PDL-derived DSCs, bone marrow-derived MSC and adipose-derived stem cells have been shown to promote periodontal tissue regeneration (42).

In a recent study (43), three kinds of dental tissue derived adult stem cells were obtained from the extracted immature molars of dogs, and ex vivo expanded PDLSC, DPSC, and periapical follicular stem cells were transplanted into the apical involvement defect. Autologous PDLSC showed the best regenerating capacity of PDL, alveolar bone and cementum as well as peripheral nerve and blood vessel which were evaluated by conventional and immune histology.

Successful therapies for PDL tissue regeneration will not only facilitate the treatment of periodontal diseases, but may also be used to improve current dental implant therapies. Numerous attempts to reconstruct periodontal tissues around dental implants revealed the challenge of avoiding fibrous tissue encapsulation and the formation of functional cementum on the implant surface (44).

\section{CONCLUDING REMARKS}

There is still much to learn about the nature, potentiality and behavior of dental stem/progenitor cells. However, the opportunities for their exploitation in dental tissue regeneration are immense and will lead to significant benefits for the management of the effects of dental disease.

Dental stem cells display multifactorial potential 
such as high proliferation rate, multi-differentiation ability, easy accessibility, high viability and easy to be induced to distinct cell lineages.

Therefore, these cells have been used for tissueengineering studies in large animals to assess their potential in preclinical applications. However, although numerous breakthroughs in stem cell research have been made thus far, their success and applicability in clinical trials remains to be ascertained. Solid research into the basic science and biology behind stem cells must be performed before scientists leap into the clinical trials. Technologies using MSC and iPS cells might be the new era of personalized medicine. The heterogeneity among patient factors and the biology of different stem cell types reinforces the need for an individual-targeted approach to stem cell therapy and other cell-based treatments.

\section{RESUMO}

Nos últimos anos, as pesquisas com células tronco têm aumentado exponencialmente devido ao reconhecimento de que seu potencial terapêutico pode melhorar a qualidade de vida de pacientes com diversas doenças, como a doença de Alzheimer, isquemias cardíacas e, até mesmo, nas pesquisas de medicina regenerativa que visa uma possível substituição de órgão perdidos, como por exemplo, os dentes. Baseado em habilidades de reparar tecidos injuriados e restaurar parcialmente as funções de um órgão, diversos tipos de células-tronco têm sido estudadas. Recentes evidências demonstram que as células-tronco são primariamente encontradas em nichos e que certos tecidos apresentam mais células-tronco que outros. Entre estes, os tecidos dentais são considerados como uma fonte rica de células-tronco mesenquimais adequado para aplicações em engenharia tecidual. Sabe-se que estas células têm o potencial de diferenciarem-se em diversos tipos celulares, incluindo osteoblastos, células progenitoras de neurônios, osteoblastos, condrócitos e adipósitos. Na odontologia, a biologia celular e a engenharia tecidual são de grande interesse, pois fornecem inovações na geração de novos materiais clínicos e ou na regeneração tecidual. Estas podem ser isoladas e crescidas em diversos meios de cultura apresentando grande potencial para ser usada na engenharia tecidual, incluindo regeneração de tecidos dentais, nervos e ossos. Recentemente, outra fonte de células tronco tem sido geradas a partir de células somáticas de humanos a um estágio de pluripotência, chamados de célulastronco pluripotente induzida (iPS) levando à criação de célulastronco específicas. Coletivamente, a multipotencialidade, altas taxas de proliferação e acessibilidade, faz das células-tronco dentárias uma fonte atrativa de células-tronco mesenquimais para regeneração tecidual. Esta revisão descreve novos achados no campo da pesquisa com células-tronco dentais e seu potencial uso na regeneração tecidual.

\section{ACKNOWLEDGEMENTS}

This study was supported in part by grants from the National Council for Scientific and Technological Development (FAPEGO to E.G., and CNPq grants \#302875/2008-5 and CNPq grants \#474642/2009 to C.E.).

\section{REFERENCES}

1. Bianco P, Robey PG, Simmons PJ. Mesenchymal stem cells: revisiting history, concepts, and assays. Cell Stem Cell 2008;2:313-319.

2. Arien-Zakay H, Lazarovici P, Nagler A. Tissue regeneration potential in human umbilical cord blood. Best Pract Res Clin Haematol 2010;23:291-303.

3. Meirelles Lda S, Nardi NB: Methodology, biology and clinical applications of mesenchymal stem cells. Front Biosci 2009;14:4281-4298.

4. Hemmat S, Lieberman DM, Most SP: An introduction to stem cell biology. Facial Plast Surg 2010;26:343-349.

5. Liao Y, Geyer MB, Yang AJ, Cairo MS. Cord blood transplantation and stem cell regenerative potential. Exp Hematol 2011;39:393341.

6. Demarco FF, Conde MCM, Cavalcanti BN, Casagrande L, Sakai VT, Nör JE. Dental pulp tissue engineering. Braz Dent J 2011;22:3-14.

7. Nör JE. Tooth regeneration in operative dentistry. Oper Dent 2006;31-36:633-642.

8. Takahashi K, Okita K, Nakagawa M, Yamanaka S. Induction of pluripotent stem cells from fibroblast cultures. Nat Protoc 2007;2:3081-3089.

9. Warren L, Manos PD, Ahfeldt T, Loh YH, Li H, Lau F, et al. Highly efficient reprogramming to pluripotency and directed differentiation of human cells with synthetic modified mRNA. Cell Stem Cell 2010;7:618-630.

10. Gronthos S, Mankani M, Brahim J, Robey PG, Shi S. Postnatal human dental pulp stem cells (DPSC) in vitro and in vivo. Proc Natl Acad Sci USA 2000;97:13625-13630.

11. Miura M, Gronthos S, Zhao M, Lu B, Fisher LW, Robey PG, et al.. SHED: stem cells from human exfoliated deciduous teeth. Proc Natl Acad Sci USA 2003;100:5807-5812.

12. Sonoyama W, Liu Y, Yamaza T, Tuan RS, Wang S, Shi S, et al. Characterization of the apical papilla and its residing stem cells from human immature permanent teeth: a pilot study. J Endod 2008;34:166-171.

13. Morsczeck C, Petersen J, Vollner F, Driemel O, Reichert T, Beck HC. Proteomic analysis of osteogenic differentiation of dental follicle precursor cells. Electrophoresis 2009;30:1175-1184.

14. Seo BM, Miura M, Gronthos S, Bartold PM, Batouli S, Brahim J, et al.. Investigation of multipotent postnatal stem cells from human periodontal ligament. Lancet 2004;364:149-155.

15. Waddington RJ, Youde SJ, Lee CP, Sloan AJ. Isolation of distinct progenitor stem cell populations from dental pulp. Cells Tissues Organs 2009; 189:268-274

16. Vencio EF, Pascal LE, Page LS, Denyer G, Wang AJ, RuoholaBaker H, et al.. Embryonal carcinoma cell induction of miRNA and mRNA changes in co-cultured prostate stromal fibromuscular cells. J Cell Physiol 2011;226:1479-1488.

17. Bakopoulou A, Leyhausen G, Volk J, Tsiftsoglou A, Garefis P, Koidis $\mathrm{P}$, et al.. Comparative analysis of in vitro osteo/odontogenic differentiation potential of human dental pulp stem cells (DPSCs) and stem cells from the apical papilla (SCAP). Arch Oral Biol 2011 [Epub ahead of print. DOI: 10.1016/j.archoralbio.2010.12.008].

18. Stevens A, Zuliani T, Olejnik C, LeRoy H, Obriot H, Kerr-Conte J, et al.. Human dental pulp stem cells differentiate into neural crestderived melanocytes and have label-retaining and sphere-forming abilities. Stem Cells Dev 2008;17:1175-1184. 
19. Yan X, Qin H, Qu C, Tuan RS, Shi S, Huang GT. iPS cells reprogrammed from human mesenchymal-like stem/progenitor cells of dental tissue origin. Stem Cells Dev 2010;19:469-480.

20. Almushayt A, Narayanan K, Zaki AE, George A. Dentin matrix protein 1 induces cytodifferentiation of dental pulp stem cells into odontoblasts. Gene Ther 2006;13:611-620.

21. He H, Yu J, Liu Y, Lu S, Liu H, Shi J, et al.. Effects of FGF2 and TGFbeta1 on the differentiation of human dental pulp stem cells in vitro. Cell Biol Int 2008;32:827-834.

22. Gronthos S, Brahim J, Li W, Fisher LW, Cherman N, Boyde A, et al.. Stem cell properties of human dental pulp stem cells. J Dent Res 2002;81:531-535.

23. Batouli S, Miura M, Brahim J, Tsutsui TW, Fisher LW, Gronthos $\mathrm{S}$, et al.. Comparison of stem-cell-mediated osteogenesis and dentinogenesis. J Dent Res 2003;82:976-981.

24. Huang GT, Yamaza T, Shea LD, Djouad F, Kuhn NZ, Tuan RS, et al.. Stem/progenitor cell-mediated de novo regeneration of dental pulp with newly deposited continuous layer of dentin in an in vivo model. Tissue Eng Part A 2010;16:605-615.

25. Kiraly M, Kadar K, Horvathy DB, Nardai P, Racz GZ, Lacza Z, et al.. Integration of neuronally predifferentiated human dental pulp stem cells into rat brain in vivo. Neurochem Int 2011;8:1-11.

26. Seo BM, Sonoyama W, Yamaza T, Coppe C, Kikuiri T, Akiyama $\mathrm{K}$, et al.. SHED repair critical-size calvarial defects in mice. Oral Dis 2008;14:428-434.

27. Govindasamy V, Abdullah AN, Ronald VS, Musa S, Ab Aziz ZA, Zain RB, et al.. Inherent differential propensity of dental pulp stem cells derived from human deciduous and permanent teeth. J Endod 2010;36:1504-1515.

28. Chueh LH, Huang GT. Immature teeth with periradicular periodontitis or abscess undergoing apexogenesis: a paradigm shift. J Endod 2006;32:1205-1213.

29. Trubiani O, Orsini G, Zini N, Di Iorio D, Piccirilli M, Piattelli A, et al.. Regenerative potential of human periodontal ligament derived stem cells on three-dimensional biomaterials: a morphological report. J Biomed Mater Res A 2008;87:986-993.

30. Lin NH, Gronthos S, Mark Bartold P. Stem cells and future periodontal regeneration. Periodontol 2000 2009;51:239-251.

31. Nygaard-Ostby B, Hjortdal O. Tissue formation in the root canal following pulp removal. Scand J Dent Res 1971;79:333-349.

32. Lovelace TW, Henry MA, Hargreaves KM, Diogenes A. Evaluation of the delivery of mesenchymal stem cells into the root canal space of necrotic immature teeth after clinical regenerative endodontic procedure. J Endod 2010;37:133-138
33. Iohara $\mathrm{K}$, Nakashima $\mathrm{M}$, Ito $\mathrm{M}$, Ishikawa $\mathrm{M}$, Nakasima $\mathrm{A}$, Akamine A. Dentin regeneration by dental pulp stem cell therapy with recombinant human bone morphogenetic protein 2. J Dent Res 2004;83:590-595.

34. Prescott RS, Alsanea R, Fayad MI, Johnson BR, Wenckus CS, Hao $\mathrm{J}$, et al.. In vivo generation of dental pulp-like tissue by using dental pulp stem cells, a collagen scaffold, and dentin matrix protein 1 after subcutaneous transplantation in mice. J Endod 2008;34:421426.

35. Cordeiro MM, Dong Z, Kaneko T, Zhang Z, Miyazawa M, Shi S, et al.. Dental pulp tissue engineering with stem cells from exfoliated deciduous teeth. J Endod 2008;34:962-969.

36. Wolf DL, Lamster IB. Contemporary concepts in the diagnosis of periodontal disease. Dent Clin North Am 2011;55:47-61.

37. AlGhamdi AS, Shibly O, Ciancio SG. Osseous grafting part I. autografts and allografts for periodontal regeneration - a literature review. J Int Acad Periodontol 2010;12:34-38.

38. Chen YL, Chen PK, Jeng LB, Huang CS, Yang LC, Chung HY, et al.. Periodontal regeneration using ex vivo autologous stem cells engineered to express the BMP-2 gene: an alternative to alveolaplasty. Gene Ther 2008;15:1469-1477.

39. Sonoyama W, Liu Y, Fang D, Yamaza T, Seo BM, Zhang C, et al. Mesenchymal stem cell-mediated functional tooth regeneration in swine. PLoS One 2006;1:e79.

40. Zaman KU, Sugaya T, Kato H. Effect of recombinant human platelet-derived growth factor-BB and bone morphogenetic protein-2 application to demineralized dentin on early periodontal ligament cell response. J Periodontal Res 1999;34:244-250.

41. He H, Yu J, Cao J, E L, Wang D, Zhang H, Liu H. Biocompatibility and osteogenic capacity of periodontal ligament stem cells on nHAC/PLA and HA/TCP scaffolds. J Biomater Sci Polym Ed 2010 [Epub ahead of print. DOI:10.1016/j.neuint.2011.01.006].

42. Taba M, Jr., Jin Q, Sugai JV, Giannobile WV. Current concepts in periodontal bioengineering. Orthod Craniofac Res 2005;8:292302.

43. Park JY, Jeon SH, Choung PH. Efficacy of periodontal stem cell transplantation in the treatment of advanced periodontitis. Cell Transplant 2010 [Epub ahead of print. DOI: 10.3727/096368910X519292].

44. Lin C, Dong QS, Wang L, Zhang JR, Wu LA, Liu BL. Dental implants with the periodontium: a new approach for the restoration of missing teeth. Med Hypotheses 2009;72:58-61.

Accepted February 28, 2011 